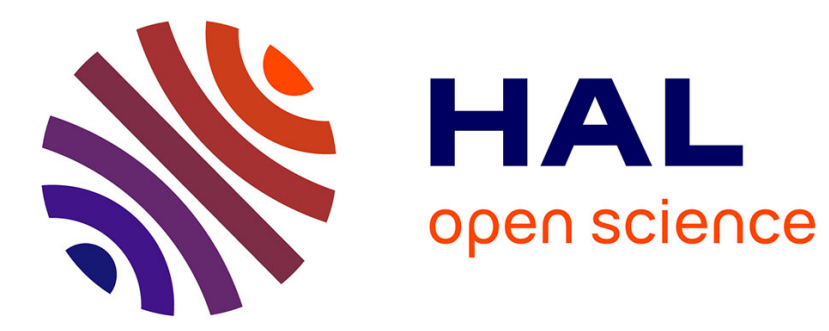

\title{
Hydrogen on unsupported ruthenium sulfide. Thermodesorption and 1H NMR studies
}

Michel Lacroix, Shibin Yuan, Michèle Breysse, Claudine Doremieux-Morin, Jacques Fraissard

\section{To cite this version:}

Michel Lacroix, Shibin Yuan, Michèle Breysse, Claudine Doremieux-Morin, Jacques Fraissard. Hydrogen on unsupported ruthenium sulfide. Thermodesorption and 1H NMR studies. Journal of Catalysis, 1992, 138, pp.409-412. hal-00006267

\section{HAL Id: hal-00006267 \\ https://hal.science/hal-00006267}

Submitted on 8 Nov 2021

HAL is a multi-disciplinary open access archive for the deposit and dissemination of scientific research documents, whether they are published or not. The documents may come from teaching and research institutions in France or abroad, or from public or private research centers.
L'archive ouverte pluridisciplinaire HAL, est destinée au dépôt et à la diffusion de documents scientifiques de niveau recherche, publiés ou non, émanant des établissements d'enseignement et de recherche français ou étrangers, des laboratoires publics ou privés. 


\section{Hydrogen on Unsupported Ruthenium Sulfide: Thermodesorption and ${ }^{1} \mathrm{H}$ NMR Studies}

The interaction of transition metal sulfides with hydrogen is a complex process. Understanding this process is important due to the very large number of industrial processes dealing with these systems. The main utilization of these catalysts concerns catalytic hydrotreating which involves hydrogenation reactions and $\mathrm{C}-\mathrm{S}, \mathrm{C}-\mathrm{N}$, and $\mathrm{C}-\mathrm{O}$ bond cleavage reactions carried out in the presence of high partial pressures of hydrogen. The complexity of the interaction of hydrogen with metal sulfides is related to its double role, as reactant and as modifier of the concentration of active sites. As a matter of fact, the interaction of hydrogen with the surface of the catalyst provokes its partial reduction, leading to coordinatively unsaturated metal ions which are directly involved in the adsorptive and catalytic properties (1).

As molybdenum sulfide is the essential component of industrial hydrotreating catalysts, its interaction with hydrogen has been the subject of many investigations. The review of Moyes (2) and the recent paper of Hall and Komatsu (3) have shown that the amount of adsorbed hydrogen changes drastically from one study to another. In order to compare easily this large number of literature data the amount of adsorbed hydrogen is often expressed using the nomenclature $\mathrm{H}_{x} \mathrm{MoS}_{2}$. Using the same preparation procedure (decomposition of ammonium tetrathiomolybdate) the values of $x$ vary between 0.012 and 0.37 . This important variation of $x$ has probably to be ascribed to different catalysts pretreatment prior to adsorption measurements, leading to different number of vacancies. This hypothesis has been demonstrated by Jalowiecki et al. (4), who have reported that the activity and the hydrogen adsorption capacity of a molybdenum-based catalyst is greatly dependent on the sulfur-to-molybdenum ratio. Concerning the chemical nature of the adsorbed species, inelastic neutron scattering studies have evidenced that dissociated hydrogen resides on sulfur anions in the form of $\mathrm{SH}$ groups $(5,6)$. This result has been recently confirmed by solid NMR spectroscopy (3). Although these techniques have never shown the presence of adsorbed hydridetype hydrogen, its presence on molybdenum or rhenium sulfides has been assumed for explaining the mechanisms of thiophene or hydrothiophene hydrodesulfurization and alkenes hydrogenation $(7,8)$.

The relation between the sulfur-to-metal ratio and the catalytic activity was also studied for other sulfides. We have recently reported that the $\mathrm{H}_{2}-\mathrm{D}_{2}$ exchange activity of a model ruthenium sulfide is drastically enhanced by sulfur removal (9). As ruthenium sulfide is one of the most active chalcogenide (13 times more active than molybdenum sulfide in the hydrodesulfurization of thiophene and 10 times in the hydrogenation of biphenyl), its activity could be related to a large adsorption capacity or to the presence of adsorbed hydrogen species different from those already detected on lamellar sulfides. To tackle this fundamental problem of hydrogen adsorption on ruthenium sulfide, we have taken the fully sulfided state as starting point and evaluated the influence of progressive desulfurization on the amount of adsorbed hydrogen. The nature of the adsorbed species was investigated using thermodesorption and ${ }^{~} \mathrm{H}$ NMR.

Ruthenium sulfide was prepared by pre- 


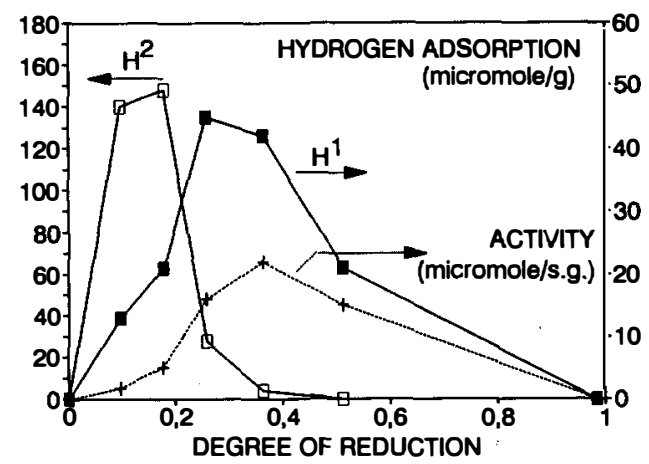

FIG. 2. Amount of adsorbed $\mathrm{H}^{1}$ and $\mathrm{H}^{2}$ and $\mathrm{H}_{2}-\mathrm{D}_{2}$ exchange activity as a function of the degree of reduction of the catalyst.

lated to $\mathrm{H}^{1}$ species follows a completely different trend, i.e., its amount increases with desulfurization, reaches a maximum for $\alpha=0.3-0.4$, and then decreases above.

This different behavior of $\mathrm{H}^{1}$ and $\mathrm{H}^{2}$ toward sulfur removal suggests that different adsorbing sites are required for hydrogen chemisorption. As the concentration of $\mathrm{H}^{2}$ decreases when the desulfurization of the solid increases, this type of hydrogen does not seem to be adsorbed on anionic vacancies but in interaction with sulfur anions as $\mathrm{SH}$ groups. This species is probably the one observed in Heise's INS work on ruthenium sulfide (10). By contrast, the amount of $\mathrm{H}^{1}$ hydrogen increases with desulfurization up to $\alpha \sim 0.4$. At this stage of the reduction, the surface of the catalyst contains a very low concentration of sulfur anions. Consequently, these experimental data suggest that $\mathrm{H}^{1}$ is adsorbed on coordinatively unsaturated ruthenium ions. The comparison of these adsorption results with those obtained previously for the $\mathrm{H}_{2}-\mathrm{D}_{2}$ exchange reaction (also reported in Fig. 2) and the 1-butene hydrogenation reaction $(9,11)$ evidences a striking similarity in their variations with $\alpha$. This strongly favours the hypothesis that $\mathrm{H}^{1}$ is the active species responsible for the hydrogenation reaction. For $\alpha>0.5$, the diminution of $\mathrm{H}^{1}$ adsorption can be ascribed to surface area collapsing and to the formation of a surface-poisoned ruthenium metal- lic phase inactive for hydrogen activation, as already proposed for the exchange reaction $(9,12-14)$.

To obtain more information about the chemical nature of $\mathrm{H}^{1}$ and $\mathrm{H}^{2}$ two samples were studies by solid ${ }^{1} \mathrm{H}$ NMR spectroscopy. Sample 1 was poorly desulfurized and presented both kinds of adsorbed hydrogen $(\alpha \sim 0.15)$, whereas sample 2 contained mostly type-1 hydrogen $(\alpha=0.35)$. Both magic-angle-spinning (MAS) spectra were recorded in sealed tubes on a Bruker MSL apparatus at $400 \mathrm{MHz}$ at room temperature. A weak rotation speed $(1 \mathrm{kHz})$ was enough to observe the signals (Fig. 3), the small widths of which characterize species moving during the time characteristic of the experiment $\left(10^{-9} \mathrm{sec}\right)$.

Figure 3 shows the results of the ${ }^{1} \mathrm{H}$ NMR. For both solids, the chemical shift relative to tetramethylsilane could be deduced with fair accuracy. Sample 1 exhibits two signals at $-7.4 \mathrm{ppm}$ and $5.1 \mathrm{ppm}$. The value of the later is consistent with an acidic character of the adsorbed species, in agreement with the hypothesis of the formation of superficial SH groups (15). The other signal, -7.4

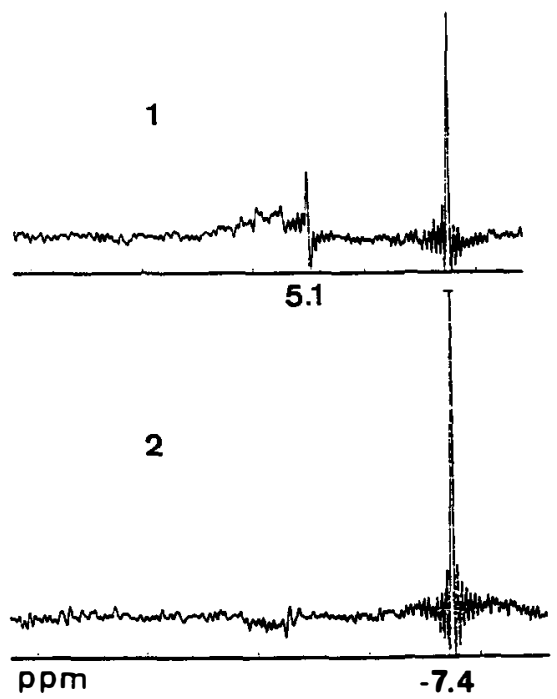

FIG. 3. Solid ${ }^{1} H$ NMR of adsorbed hydrogen. The degree of reduction is 0.15 for sample 1 and 0.35 for sample 2 . 
ppm (upfield), can be most likely ascribed to a hydride-type species (16-20).

To sum up, the characterization of hydrogen adsorbed on partially desulfurized ruthenium sulfide has evidenced two different species: one leading to the formation of $\mathrm{SH}$ groups and the other with hydridic character being chemisorbed on coordinatively unsaturated ruthenium cations. The latter, related to the hydrogenating properties of the catalyst, probably explains the high activity of ruthenium sulfide.

\section{REFERENCES}

1. Siegel, S., J. Catal. 30, 139 (1973).

2. Moyes, R. B., in "Hydrogen Effects in Catalysis" (P. Zoltan and P. G. Menon, Eds.), p. 583. Dekker, New York-Basel, 1988.

3. Komatsu, T., and Hall, K., J. Phys. Chem. 95, 9966 (1991).

4. Jalowieki, L., Aboulaz, A., Kasztelan, S., Grimblot, J., and Bonnelle, J. P., J. Catal. 120, 108 (1989).

5. Sampson, C., Thomas, J. M., Vasudevan, S., and Wright, C. J., Bull. Soc. Chim. Belg. 90(12), 1215 (1981).

6. Wright, C., Sampson, C., Fraser, D., Moyes, R. B., and Wells, P. B., J. Catal. 116, 11 (1989).

7. Markel, E. J., Shrader, G. L., Sauer, N. N., and Angelici, R. J., J. Catal. 132, 253 (1989).

8. Tanaka, K., Adv. Catal. 33, 99 (1985).

9. Yuan, S., Decamp, T., Lacroix, M., Mirodatos, C., and Breysse, M., J. Catal. 132, 253 (1991).

10. Heise, W. H., Lu, K., Kuo, Y. J., Udovic, T. J., Rush, J. J., and Tatarchuk, B. J., J. Phys. Chem. 92, 5184 (1988).

11. Lacroix, M., Mirodatos, C., Breysse, M., Decamp, T., and Yuan, S., Preprint, 10th International Congress on Catalysis, 19-24 July, 1992, Budapest, Hungary, oral paper 34.
12. Lu, K., Kuo, Y. J., and Tatarchuck, B. J., J. Catal. 116, 373 (1989).

13. Knop, O., Can. J. Chem. 41, 1838 (1963)

14. Brand, J. L., Deckert, A. A., and George, S. M., Surf. Sci. 194, 457 (1988)

15. Freude, D., Stud. Surf. Sci. Catal. 52, 169 (1989).

16. Buckingham, A. D., and Stefens, P. J., J. Chem. Soc., 2747 (1964).

17. Holm, R. H., and Hawkins, C. J., in "NMR of paramagnetic molecules. Principles and applications" (G. N. LaMar, W. De Horrocks, and R. H. Holm, Eds.), p. 286. Academic Press, New York, 1973.

18. De Ménorval, L. C., and Fraissard, J. P., in "Growth and Properties of Metal Clusters" (J. Bourdon, Ed.), p. 151. Elsevier, Amsterdam, 1980.

19. De Ménorval, L. C., and Fraissard, J. P., Chem. Phys. Lett. 77, 309 (1981).

20. King, T. S., Wu, X., and Gerstein, B. C., J. Am. Chem. Soc. 108, 6056 (1986).

\section{Michel Lacroix ${ }^{1}$ SHIBIN YUAN \\ MICHÈLE BREYSSE}

Institut de Recherches sur la Catalyse

2, Avenue Albert Einstein

69626 Villeurbanne cédex, France

\section{Claudine Dorémieux-Morin JACQUES FRAISSARD}

Laboratoire de Chimie des Surfaces URA 1428

Université Pierre et Marie Curie

4, place Jussieu - Tour 55, BP 196

75252 Paris cédex, France

\footnotetext{
${ }^{1}$ To whom correspondence should be addressed.
} 